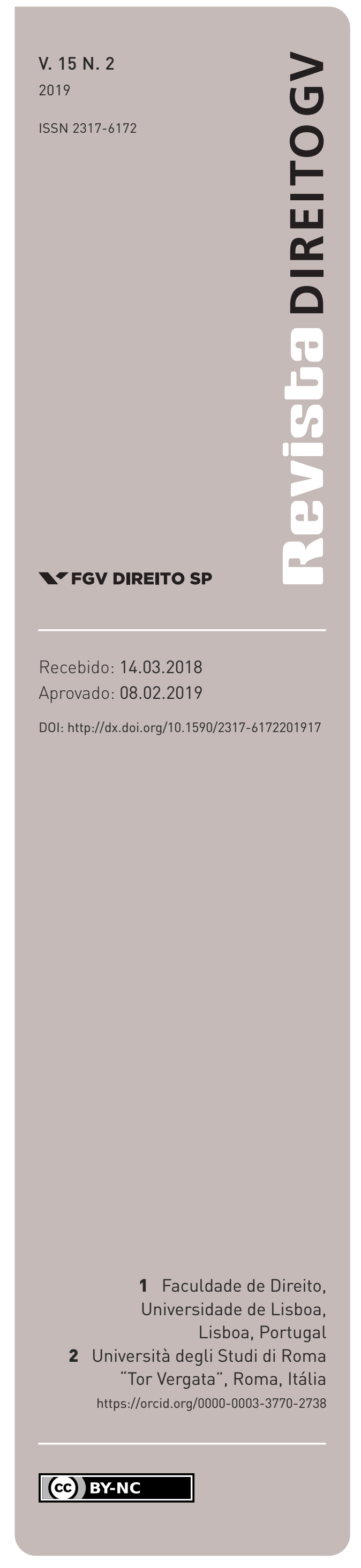

\section{A ponderação de regras e alguns problemas da teoria dos princípios de Robert Alexy}

THE BALANCING OF RULES AND SOME PROBLEMS OF THE ROBERT ALEXY'S PRINCIPLES THEORY

\author{
Bruno Sacramento ${ }^{1,2}$
}

\section{Resumo}

Este artigo versa sobre a distinção entre regras e princípios e analisa alguns aspectos da difundida tese da distinção qualitativa sustentada por Ronald Dworkin e Robert Alexy. A partir de um exemplo que envolve duas normas da Constituição brasileira que tratam da substituição do presidente da República, e por meio de uma abordagem analítica, adere-se a uma crítica que envolve um dos principais elementos da teoria dos princípios: a de que a ponderação é a forma de aplicação dos princípios. Defende-se que a ponderação é uma técnica de resolução de conflitos normativos que, excepcionalmente, pode ser usada também para aplicação de regras, do que decorre diversas consequências. São abordados, assim, alguns tópicos essenciais nesse contexto, como derrotabilidade normativa, caráter prima facie, subsunção e ponderação, dimensão de peso e mandamentos de otimização. No final, tendo em conta as críticas referidas, expõe-se um possível critério de distinção com base nas diferenças comportamentais e estruturais existentes entre as espécies normativas.

\section{Palavras-chave}

Teoria dos princípios; conflitos normativos; ponderação; mandamentos de otimização; derrotabilidade.

\section{Abstract}

This paper deals with the distinction between rules and principles and analyzes some aspects of the widespread thesis of the qualitative distinction supported by Ronald Dworkin and Robert Alexy. From an example involving two norms of the Brazilian Constitution that treat of the substitution of the President of the Republic, and through an analytical approach, assent to a critique that involves one of the main elements of the theory of principles: that balancing is the form of application of the principles. It is argued that balancing is a technique for solving normative conflicts which, exceptionally, can also be used for the application of rules, resulting in several consequences. Thereby, some essential topics in this context are discussed, such as normative defeasibility, prima facie character, subsumption and balancing, dimension of weight and optimization requirements. In the end, taking into account the criticisms pointed out, a possible criterion of distinction is exposed based on the behavioral and structural differences between the normative species.

\section{Keywords}

Principles theory; normative conflicts; balancing; optimisation requirements; defeasibility. 


\section{INTRODUÇÃO}

A discussão existente no âmbito da teoria das normas e que versa sobre a distinção entre regras e princípios não é recente. Segue, entretanto, despertando interesse, o que gera intensa produção bibliográfica e diferentes propostas referentes aos possíveis critérios de diferenciação.

Nesse cenário, inegavelmente a tese da diferença qualitativa defendida por Ronald Dworkin e, depois, utilizada e desenvolvida por Robert Alexy, ganhou destaque e grande acolhida doutrinária, seja no contexto internacional, seja no brasileiro.

Em 2003, ao inventariar a definição de princípio constante na literatura jurídica brasileira, Virgílio Afonso da Silva (2003, p. 612-615) apontou que o critério da fundamentalidade era o predominante, no sentido de que se nominava princípio aquelas normas nucleares, mais fundamentais do sistema, de acordo com seu próprio conteúdo.

O quadro atual, porém, é diverso. Pode-se afirmar que a teoria defensora da diferença qualitativa, que dispensa a análise do conteúdo da norma para classificá-la como princípio ou regra, tornou-se dominante. Nesse sentido, entre outros aspectos, consolidaram-se na doutrina brasileira as lições de que as regras são mandamentos definitivos, aplicando-se na forma do tudo ou nada, enquanto os princípios são mandamentos de otimização, com comandos prima facie. E igualmente a de que as regras se aplicam por subsunção e os princípios, por ponderação. ${ }^{1}$

Tal teoria, porém, tem recebido diversas críticas no Brasil e no exterior, seja por fragilidades de alguns de seus pressupostos, seja pela forma como vem sendo recepcionada e aplicada pelos tribunais, sendo este último tipo delas o predominante no Brasil.

Neste artigo, procura-se fundamentalmente expor uma crítica que se considera acertada e que atinge um dos pilares da teoria dos princípios: ${ }^{2}$ a de que a ponderação não é apenas a forma de aplicação dos princípios, mas uma técnica de resolução de conflitos normativos que se aplica também às regras em determinadas situações.

Com a intenção de demonstrar sua correção, será examinado um exemplo de conflito normativo entre regras da Constituição brasileira que só pode ser resolvido por meio de uma ponderação. Trata-se das normas que estabelecem quem poderá assumir, em caráter provisório, o cargo de presidente da república em caso de dupla vacância ou duplo impedimento,

1 Entre tantos, cf. o próprio Virgílio Silva (2010, p. 44 ss.), Barroso (2017, p. 244-245 e 360) e Mendes e Branco (2016, p. 181 ss.). Para propostas diferentes, cf. Neves (2013) e Ávila (2014).

2 Cabe alertar, assim, que o trabalho se enquadra no primeiro tipo referido, tendo como propósito exclusivo contribuir para o debate por meio de uma análise crítica da própria teoria, e não de sua eventual má recepção ou utilização pelos tribunais. Sobre esses aspectos, inclusive no que se refere a uma possível “absolutização de princípios” e a uma "compulsão ponderadora” no Brasil, cf. Neves (2013, p. 171 ss.). Sobre a importância de se separar essas duas perspectivas no tratamento da matéria, cf. Silva (2016, p. 112-113). 
ou seja, quando os cargos de presidente e vice-presidente da República ficarem simultaneamente desocupados. ${ }^{3}$

A linha de raciocínio será desenvolvida do seguinte modo: após alguns breves apontamentos sobre a teoria dos princípios, na forma em que é sustentada por Dworkin e Alexy, será apresentado o mencionado conflito normativo sujeito à ponderação; em seguida, serão analisadas as consequências que o reconhecimento da ponderação entre regras pode trazer para a teoria dos princípios, bem como alguns outros problemas conexos; por fim, serão feitas algumas considerações sobre o que resta como possível critério para diferenciar regras e princípios.

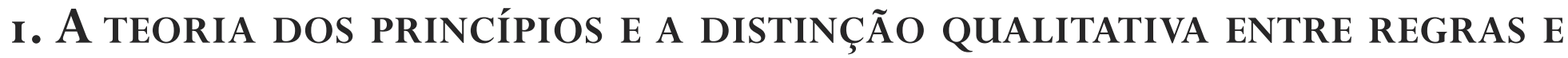 PRINCÍPIOS - RONALD DWORKIN E ROBERT ALEXY}

Ronald Dworkin e Robert Alexy defendem uma separação forte entre regras e princípios em função da diferente estrutura lógica das espécies normativas. Não se trata, portanto, de uma distinção apenas de grau, que é identificada como tese da separação fraca. ${ }^{4}$

Ronald Dworkin desenvolve sua teoria com o propósito inicial de atacar o positivismo jurídico hartiano e sustenta que os sistemas jurídicos não são compostos apenas de regras, mas também de princípios. ${ }^{\mathbf{5}}$ Esse autor defende, então, a diferenciação entre regras e princípios em função das diferentes capacidades regulativas.

As regras seriam razões definitivas para agir, ou seja, possuiriam as condições necessárias e suficientes para desencadear as consequências jurídicas por elas previstas, o que só não ocorreria em caso de invalidade. As regras, assim, se aplicariam na lógica do tudo ou nada

3 A rigor, trata-se dos casos de dupla vacância, duplo impedimento, impedimento-vacância e vacância-impedimento. Por simplificação, serão utilizadas apenas as primeiras duas expressões para englobar todos os casos.

4 Diversos autores defendem a separação fraca ou débil. Entre tantos, cf. Pino (2010, p. 54). Para verificação dos mais diversos critérios distintivos propostos, cf. Canotilho (2003, p. 1160-1161), Pino (2016, p. 76 ss.) e Neves (2013, p. 12 ss.).

5 Direcionando seu ataque contra a teoria que descreve o Direito como um sistema de regras primárias e secundárias, Dworkin demonstra sua insuficiência no que se refere à aplicação do Direito nos casos difíceis, quando o juiz não identifica nenhuma regra para resolver o caso, e a solução, então, ficaria submetida à plena discricionariedade judicial. A partir daí, Dworkin argumenta que, além das regras, há de se reconhecer os princípios. Os princípios seriam extraídos da moral e aplicáveis independentemente da regra de reconhecimento. Com isso, contrapõe-se à tese positivista da separação entre o Direito e a moral. Após a crítica dworkiniana, o próprio Hart reconhece o déficit de sua teoria no que se refere à aplicação do Direito e ao reconhecimento dos princípios. Além disso, diversos foram os desenvolvimentos e as respostas do positivismo à crítica de Dworkin. Não há, todavia, razão para maiores detalhamentos sobre o tema neste trabalho. Sobre o ponto, cf. Dworkin (1967, p. 37 ss.) e Hart (1994, p. 238 ss.). 
(all-or-nothing fashion). Ocorrido o fato que preenche seu antecedente, ${ }^{6}$ ou ela é válida, incidirá e produzirá seus efeitos, ou não é válida e não contribuirá em nada para a solução do caso (DWORKIN, 2002, p. 39). ${ }^{7}$

Os princípios, por sua vez, seriam meras razões prima facie, razões que indicam uma ou outra decisão, mas que podem não prevalecer em função da precedência de outro princípio. Eles teriam uma dimensão de peso que se revelaria nos casos de colisão, visto que sua aplicação dependeria do peso ou da importância que a eles sejam dados em função das circunstâncias do caso concreto. Nenhum deles, portanto, seria declarado inválido, apenas considerado mais importante para determinada decisão.

Robert Alexy desenvolve as lições de Dworkin, introduz a ideia de que os princípios são mandamentos de otimização e utiliza a teoria dos princípios como base de uma teoria dogmática dos direitos fundamentais.

Assim, para o autor, os princípios como mandamentos de otimização são normas que se aplicam de forma gradual, ordenam que algo seja realizado na maior medida possível, progressivamente, dentro das possibilidades fáticas e jurídicas presentes no caso. ${ }^{8} \mathrm{O}$ âmbito das possibilidades jurídicas é determinado pelas normas colidentes (ALEXY, 2011a, p. 90-91).

Além disso, de forma assemelhada ao que já defendia Dworkin, as regras seriam mandamentos definitivos, conclusivos, exigindo que seja feito exatamente aquilo que determinam, enquanto os princípios possuiriam apenas comandos provisórios, regulando prima facie. Segundo Alexy (2011a, p. 103 ss.), porém, as regras podem eventualmente perder o caráter definitivo e adquirir um caráter prima facie em razão da possível inclusão de uma exceção principiológica. Nesses casos, o caráter prima facie das regras e dos princípios seria distinto, porquanto em favor daquelas há que se considerar o reforço dos princípios formais, especialmente no sentido de que se devem respeitar as regras criadas pela autoridade legitimada.

6 A estrutura básica da norma jurídica tem um antecedente (suporte fático, previsão ou hipótese), que prevê as condições (ou pressupostos) de sua aplicação; um operador deôntico, que expressa uma imposição, uma proibição ou uma permissão; e um consequente (consequência jurídica, estatuição ou conteúdo), que estabelece a consequência jurídica, o que se deve verificar em função do preenchimento das condições previstas no antecedente normativo. Neste artigo, será dada preferência para a utilização da nomenclatura antecedente, operador deôntico e consequente.

7 O pressuposto da ideia de Dworkin é que seria possível enumerar exaustivamente todas as possíveis exceções à aplicabilidade das regras.

8 Posteriormente, Alexy vincula a ideia de mandamento de otimização à ideia de um "dever ideal", que seria expressado pelos princípios, em oposição ao “dever real”, expressado pelas regras (ALEXY, 2000, p. 300-301). Tais conceitos e seus desdobramentos serão explicitados na sequência deste artigo. 
As diferenças também se revelariam marcantes no caso de conflito ou colisão (ALEXY, 2011 a, p. 91 ss.).

Em caso de conflito que envolve regras, que ocorre na dimensão da validade, ou é incluída uma cláusula de exceção em razão de outra regra ou mesmo de um princípio, ou ela é considerada inválida, sendo retirada do ordenamento jurídico.

Os princípios, no entanto, por ordenar que algo seja realizado na maior medida possível, frequentemente colidem com outros princípios. Nesses casos, a solução da colisão e a otimização ocorrem por meio de uma ponderação, quando se definirá o princípio a prevalecer no caso concreto, sem que haja declaração de invalidade daquele que for preterido.

Por fim, uma das grandes diferenças entre regras e princípios seria, então, sua forma de aplicação: as regras por subsunção e os princípios por ponderação (ALEXY, 2012, p. 512-513).

Resumidamente, essas são as características gerais da teoria dominante. Outros aspectos, porém, serão abordados em alguns dos tópicos a seguir, apenas quando imprescindíveis ao desenvolvimento das ideias.

\section{Ponderando Regras: a ponderação como técnica subsidiária de RESOLUÇÃO DE CONFLITOS NORMATIVOS E O CASO QUE ENVOLVE A SUBSTITUIÇÃO PRESIDENCIAL NO BRASIL}

\section{I. A PONDERAÇÃO COMO UMA INEVITABILIDADE}

Distanciando-se da visão anteriormente exposta, entende-se que a ponderação não é a forma de aplicação dos princípios, mas a técnica de resolução de conflitos normativos não solucionáveis por normas de resolução de conflitos, como aquelas que determinam a prevalência das normas hierarquicamente superiores, das posteriores e das especiais.

Conflitos com essa característica podem ocorrer entre princípios, o que é mais comum, mas também entre regras. Basta que os fatos relevantes de determinado caso preencham o antecedente de mais de uma norma, que elas possuam efeitos contraditórios ou incompatíveis e que entre elas não exista relação de hierarquia, especialidade ou anterioridade.

Em situações como essa, não há solução oferecida pelo sistema para definição do estatuto deôntico da ação. Há, no entanto, a vedação do non liquet. O juiz deve decidir, não podendo se limitar a demonstrar a existência do conflito normativo.

Nesses casos, não há alternativa, razão pela qual a ponderação surge como uma inevitabilidade.

Um conhecido exemplo da doutrina (ZORRILLA, 2011, p. 733) ajuda a clarificar o afirmado. Trata-se do conflito hipotético entre as seguintes normas-regra:

(1) $\mathrm{N}^{1}$ : é obrigatório parar no sinal vermelho.

(2) $\mathrm{N}^{2}$ : é obrigatório circular em zonas militares. 
Se um condutor está diante de um sinal vermelho localizado em uma zona militar, ele deve parar ou circular?

No exemplo, o fato aciona duas normas com efeitos incompatíveis e, supondo que não há como solucionar o caso por meio das normas tradicionais de resolução de conflito, não resta alternativa senão ponderar.

A ponderação como técnica subsidiária de resolução de conflitos normativos em geral tem sido defendida por diversos autores (por exemplo, DUARTE, 2010, p. 51 ss.; SIECKMANN, 2010, p. 101; e LOPES, 2016, p. 126). ${ }^{9}$ Ainda assim, entende-se pertinente expor em detalhes um exemplo de possível conflito normativo entre duas regras da Constituição brasileira como forma de ilustrar e confirmar o aqui afirmado, configurando objeto do tópico seguinte.

\subsection{A SUbSTITUIÇÃo TEMPORÁria dA PRESIDÊNCIA DECIDIDA POR PONDERAÇÃO}

A grave crise política enfrentada pelo Brasil, com o impeachment de uma presidente e a situação de fragilidade de seu sucessor, ${ }^{10}$ despertou o interesse para as normas constitucionais que tratam dos casos de substituição e sucessão presidencial.

A primeira questão que se coloca é analisar quem deve assumir a presidência em caso de dupla vacância ou duplo impedimento, isto é, quando ficam simultaneamente vagos ou temporariamente desocupados os cargos de presidente e vice-presidente da República. ${ }^{11}$

Nos casos de dupla vacância, tendo em vista seu caráter definitivo, ocorre a sucessão presidencial. ${ }^{12}$ A forma de escolha do novo presidente depende do momento em que ocorre a dupla vacância. Se ocorrer nos primeiros dois anos do mandato, serão realizadas novas eleições diretas 90 dias depois de vagar o último cargo. Se, no entanto, ocorrer nos dois últimos anos,

9 Admitindo a ponderação de regras, cf. Peczenik (2008, p. 66) e, na doutrina brasileira, Ávila (2014, p. 74 ss.). Contra: Silva (2010, p. 56 ss.).

10 A ex-presidente Dilma Rousseff foi afastada definitivamente do cargo em razão de pedido de impeachment julgado pelo Senado Federal em 2016, quando assumiu o então vice-presidente Michel Temer. Este, por sua vez, poderia ter sido afastado em virtude da Ação de Investigação Judicial Eleitoral n. 1.943-58, na qual se discutia a prática de abuso de poder político e econômico nas eleições de 2014, o que levaria à cassação da chapa (presidente e vice). Houve absolvição, entretanto, no julgamento realizado no Tribunal Superior Eleitoral (TSE) em 2017. No mesmo ano, Temer poderia também ter sido afastado cautelarmente caso o Supremo Tribunal Federal (STF) recebesse duas denúncias apresentadas pela Procuradoria-Geral da República (PGR) em função da alegada prática de crimes de corrupção passiva, organização criminosa e obstrução de justiça, porém a Câmara dos Deputados não autorizou o processamento, impedindo o STF de analisá-las e de, eventualmente, instaurar o processo penal até o término do mandato.

11 A vacância ocorre em caso de afastamentos definitivos, como renúncia ou morte, e o impedimento, em casos de afastamentos temporários, como doença ou compromissos no exterior. 
serão realizadas eleições indiretas 30 dias após vagar o último cargo, cabendo, portanto, ao Congresso Nacional escolher o sucessor presidencial. ${ }^{13}$

Já nos casos de duplo impedimento, quando o afastamento dos titulares é apenas temporário, ou mesmo no caso de dupla vacância, mas apenas no período que antecede as novas eleições e posse do sucessor, ocorre a chamada substituição presidencial. A substituição, portanto, tem sempre caráter temporário.

A norma extraída do art. 80 da Constituição determina quem são os legitimados a exercer a presidência temporariamente, os chamados substitutos eventuais. Estabelece, ainda, uma ordem de preferência obrigatória entre eles. ${ }^{14}$ Esta é, então, a primeira norma que interessa ao caso:

(3) $\mathrm{N}^{1}$ : se ocorrer dupla vacância ou duplo impedimento, é obrigatório chamar ao exercício da Presidência da República os titulares dos seguintes cargos, nesta ordem: o presidente da Câmara dos Deputados, o do Senado Federal e o do Supremo Tribunal Federal.

Ocorre que nem sempre esses legitimados estarão autorizados a assumir. Há determinadas situações que impedem o exercício da presidência, seja por quem já exerce, caso em que haverá afastamento por suspensão, seja por quem deveria ser chamado a exercer, caso em que haverá proibição de iniciar o exercício.

Essas situações são as previstas no art. $86, \S 1^{\circ}$, da Constituição, ${ }^{15}$ impedindo o exercício da presidência por quem for réu em processo no STF, em razão do possível cometimento de infrações penais comuns, ou for réu perante o Senado Federal, em decorrência do possível cometimento de crime de responsabilidade.

Interpretando-se o referido enunciado normativo, fica evidente a existência da norma que impõe o afastamento cautelar do presidente da República do exercício de suas funções desde o momento em que se torna réu no STF ou no Senado.

No entanto, há outra norma a ser extraída do mesmo dispositivo legal. É justamente aquela que se dirige aos substitutos eventuais. Essa foi a interpretação realizada pelo STF nos

13 Em qualquer dos casos, o sucessor irá apenas complementar o período do sucedido (o chamado mandato-tampão), conforme o art. $81, \S 2^{\circ}$, da Constituição.

14 Este é o enunciado normativo: "Art. 80. Em caso de impedimento do Presidente e do Vice-Presidente, ou vacância dos respectivos cargos, serão sucessivamente chamados ao exercício da Presidência o Presidente da Câmara dos Deputados, o do Senado Federal e o do Supremo Tribunal Federal”.

15 “Art. 86. Admitida a acusação contra o Presidente da República, por dois terços da Câmara dos Deputados, será ele submetido a julgamento perante o Supremo Tribunal Federal, nas infrações penais comuns, ou perante o Senado Federal, nos crimes de responsabilidade.

$\S 1^{\circ} \mathrm{O}$ Presidente ficará suspenso de suas funções: 
autos da Arguição de Descumprimento de Preceito Fundamental (ADPF) n. $402{ }^{16}$ O tribunal entendeu que as mesmas situações que ensejam a suspensão do presidente se aplicam aos substitutos eventuais, impedindo seu chamamento ao exercício temporário da Presidência da República. Desse modo, no chamamento previsto no art. 80, deve-se desprezar aquele legitimado que ostentar a condição de réu. ${ }^{17}$

Essa segunda norma extraída pelo STF do enunciado normativo do art. $86, \S 1^{\circ}$, da Constituição, é a que interessa para este artigo. Assim:

(4) $\mathrm{N}^{2}$ : se for recebida denúncia ou queixa contra os substitutos da presidência pelo STF, ou contra eles for instaurado pelo Senado processo por crime de responsabilidade, é proibido chamá-los ao exercício da presidência. ${ }^{18}$

Como se vê, há uma norma (3) que identifica e estabelece a ordem daqueles que devem ser chamados ao exercício da presidência e há outra (4) que impede que eles sejam convocados se forem réus. Segundo o STF, se o primeiro for réu, deve-se chamar o segundo, e assim por diante.

I - nas infrações penais comuns, se recebida a denúncia ou queixa-crime pelo Supremo Tribunal Federal; II - nos crimes de responsabilidade, após a instauração do processo pelo Senado Federal”.

16 Trata-se do julgamento apenas do pedido de medida liminar da ADPF n. 402, realizado em 07/12/2016 (disponível em: http: / / portal.stf.jus.br/processos/detalhe.asp?incidente=4975492; acesso em: 10 jun. 2019). O pedido da ação era impedir o exercício da chefia da Câmara, do Senado e do Supremo Tribunal por aqueles que figurassem como réus. Após o deferimento integral do pedido liminar por decisão monocrática do ministro Marco Aurélio Mello, a decisão foi apenas parcialmente ratificada pelo Plenário, entendendo-se que a proibição se aplica aos substitutos eventuais, mas apenas para o exercício da Presidência da República, e não para o exercício dos demais cargos que titularizam. O mérito do processo ainda não foi julgado.

17 Nas palavras do ministro Celso de Mello, "os substitutos eventuais do Presidente da República, se tornados réus criminais perante o Supremo Tribunal Federal, não poderão ser convocados para o desempenho transitório do ofício presidencial, pois não teria sentido que, ostentando a condição formal de acusados em juízo penal, viessem a dispor de maior poder jurídico, ou de maior aptidão, que o próprio Chefe do Poder Executivo da União, titular do mandato presidencial". Nesse caso, prossegue o ministro, "a substituição a que se refere o art. 80 da Constituição Federal processar-se-á per saltum, de modo a excluir aquele que, por ser réu criminal perante o Supremo Tribunal Federal, está impedido de desempenhar o ofício de Presidente da República” (ADPF n. 402/STF).

18 Naturalmente, é possível questionar a correção da decisão do Supremo nesse caso e, consequentemente, a validade da norma reconhecida. Não é objetivo deste artigo, entretanto, analisar em detalhes o mérito da decisão. Para o que aqui importa, basta que se considere plausível uma interpretação do texto do art. $86, \S 1^{\circ}$, que extraia uma norma como a descrita, nos moldes do que considerou o STF. Neste artigo, assume-se a plausibilidade da referida interpretação e, com isso, da validade da norma, com as consequências a seguir expostas. 
Contudo, a grande questão é: e, se todos os substitutos forem réus no STF, quem deverá exercer a presidência?

Nesse caso, há uma hipotética situação de fato ${ }^{19}$ que convoca a aplicação simultânea de duas normas-regra. Simplificadamente, ilustra-se:

(5) Se há necessidade de convocar um substituto presidencial em razão de dupla vacância ou duplo impedimento, mas todos eles são réus no STF.

(6) $\quad \mathrm{N}^{1}=\mathrm{R}$ (se há dupla vacância ou duplo impedimento, é obrigatório chamar ao exercício da presidência os titulares dos seguintes cargos, nesta ordem: o presidente da Câmara dos Deputados, o do Senado Federal e o do STF).

(7) $\quad \mathrm{N}^{2}=\mathrm{R}$ (se o presidente da Câmara, o do Senado e o do STF forem réus no STF, é proibido chamá-los ao exercício da Presidência da República).

Para que se configure um conflito normativo, é necessário que duas ou mais normas tenham similares condições de aplicação (hipóteses legais) e que suas consequências jurídicas sejam incompatíveis entre si.

Como se percebe, a situação fática - necessidade de chamar os substitutos ao exercício da presidência no momento em que todos eles respondem a processo penal no STF - atrai a incidência de duas normas-regra que possuem idênticos consequentes (chamar ao exercício da Presidência da República), mas operadores deônticos contraditórios e efeitos incompatíveis: o que a $\mathrm{N}^{1}$ (6) impõe, a $\mathrm{N}^{2}$ (7) proíbe.

Esta é a descrição lógica:

(8) $\quad \mathrm{N}^{1}(6)[\forall \mathrm{X}][\mathrm{xa} \rightarrow \mathrm{I} \mathrm{xy}]$, em que $(\mathrm{a})=\operatorname{dupla}$ vacância, $(\mathrm{I})=$ imposto, $(\mathrm{y})=$ chamar à presidência.

(9) $\quad \mathrm{N}^{2}(7)[\forall \mathrm{X}][\mathrm{xb} \rightarrow \operatorname{Pr} \mathrm{xy}]$, em que $(\mathrm{b})=$ forem réus no STF, $(\operatorname{Pr})=\operatorname{proibido,}(\mathrm{y})=$ chamar à presidência.

19 A hipótese, entretanto, não parece ser de difícil ocorrência na realidade. Em 2016, os então presidentes da Câmara e do Senado, respectivamente, Eduardo Cunha e Renan Calheiros, tornaram-se réus. Já os presidentes que os sucederam, Rodrigo Maia e Eunício Oliveira, são investigados no âmbito da Operação Lava-Jato em inquéritos cuja abertura foi autorizada pelo STF. Deve-se registrar, ainda, que, em caso de processo por crime de responsabilidade do presidente da República (pedido de impeachment), o julgamento ocorre no Senado Federal, em sessão a ser presidida pelo presidente do STF, conforme previsão expressa no art. 52, parágrafo único, da Constituição. Há, nesse caso, dúvida sobre a possibilidade de o presidente do STF - último legitimado - assumir a presidência, porquanto ensejaria seu impedimento para presidir o julgamento do impeachment. Sobre o impedimento, cf. Brindeiro (2009, p. 1.181). 
Já o requisito das condições similares de aplicação fica mais claro quando se recorda que as normas são generalizações deônticas, ${ }^{\mathbf{2 0}}$ implicando que sejam válidas para todas as situações. Assim, de acordo com $\mathrm{N}^{1}$ (6), é verdade que, quando há dupla vacância ou duplo impedimento, devem-se chamar à presidência os substitutos em todas as situações, ainda que sejam réus no STF ou no Senado. E, pela $\mathrm{N}^{2}$ (7), é verdade que é proibido chamar os substitutos à presidência quando forem réus em todas as situações, inclusive quando houver dupla vacância ou duplo impedimento. ${ }^{21}$

Assim, na verdade, se há dupla vacância e todos forem réus no STF, considerando o anteriormente exposto, no esquema lógico:

(10) $\mathrm{N}^{1}(6)[\forall \mathrm{X}][\mathrm{xa} \wedge \mathrm{xb} \rightarrow \mathrm{I} \mathrm{xy}]$, em que (a) $=$ dupla vacância, $(\mathrm{b})=$ forem réus, $(\mathrm{I})=$ imposto, $(\mathrm{y})=$ chamar à presidência.

(11) $\mathrm{N}^{2}(7)[\forall \mathrm{X}][\mathrm{xb} \wedge \mathrm{xa} \rightarrow \operatorname{Pr} \mathrm{xy}]$, em que $(\mathrm{b})=$ forem réus, $(\mathrm{a})=$ dupla vacância, $(\operatorname{Pr})=$ proibido, $(\mathrm{y})=$ chamar à presidência.

(12) $\mathrm{N}^{1}=p, \mathrm{~N}^{2}=\ulcorner p$

As normas possuem, portanto, condições similares de aplicação e efeitos contraditórios, configurando um conflito normativo. ${ }^{22}$ Não há, todavia, relação de hierarquia, especialidade ou anterioridade entre elas, visto que ambas têm estatura constitucional, são normas originárias da Constituição de 1988 , e suas condições de aplicação não indicam que alguma delas é especial ou geral em relação à outra, o que impõe a utilização da ponderação como técnica de solução do conflito.

Essa conclusão fica evidente quando se verifica que, considerando as condições similares de aplicação, estabelece-se entre elas um conflito identificado como parcial-parcial. Isso ocorre quando o âmbito de aplicação de uma norma é parcialmente comum e parcialmente distinto do âmbito de aplicação de outra. Assim, as normas possuem em seus respectivos antecedentes algumas condições em comum e algumas condições que não estão presentes na outra.

Desse modo, como as tradicionais normas de prevalência não se aplicam e o ordenamento jurídico brasileiro não possui qualquer outra norma secundária capaz de solucionar

Sobre o ponto, cf. Lopes (2016, p. 56 ss. e 270-271). Em geral, sobre as normas como generalizações, cf. Schauer (1991, p. 17 ss.).

21 A afirmação é verdadeira, mesmo que, no contexto do Direito positivo vigente, aparentemente, seja esse o único caso de aplicação.

22 Em razão dos limites deste trabalho, não há como aprofundar o tema dos conflitos normativos. Sobre o ponto, entre outros, cf. Zorrilla (2007, p. 59 ss.) e Lopes (2016, p. 228 ss.). Especificamente, sobre as condições de um conflito normativo que ensejam a solução por ponderação, cf. Duarte (2010, p. 57 ss.). 
esse relevante conflito normativo, a única alternativa seria a realização de uma inevitável ponderação entre as duas regras.

\section{A Derrotabilidade das Regras e SEU CARÁter prima FACIE}

A derrotabilidade (defeasibility), ainda que possua conceitos mais amplos ou restritos, é o fenômeno ligado à possibilidade de acomodar exceções. Sua introdução na Filosofia do Direito ocorreu em 1948 por meio de um texto de Hart (1948, p. 171-194), ${ }^{23}$ e nos últimos anos passou a ganhar destaque em diversos trabalhos. ${ }^{24}$

O estudo da derrotabilidade das normas jurídicas tem se mostrado de grande relevância nas discussões sobre a distinção entre regras e princípios, justamente por estar ligado ao caráter prima facie ou definitivo das normas.

A possibilidade de excepcionalmente não ocorrer a ativação das consequências jurídicas de uma norma, mesmo que preenchidas as condições de seu antecedente, demonstra que essas condições são apenas necessárias, mas não suficientes. Para que ocorra o efeito jurídico previsto, deve-se verificar as outras normas relevantes para o caso concreto em que podem, em razão de eventuais efeitos colidentes, derrotar a norma de partida (LOPES, 2016, p. 124-125). O fenômeno da derrotabilidade atesta, assim, o caráter prima facie das normas.

Esse fenômeno é verificado, porém, tanto com as regras quanto com os princípios. As regras podem ser derrotadas pela inclusão de uma exceção em razão de um princípio de sinal contrário ou, como se viu, em decorrência de um conflito só solucionável por ponderação.

O caráter prima facie, portanto, não é característica apenas dos princípios, mas também das regras, que não regulam em caráter definitivo, conforme defendido por Dworkin. Não se verifica nem mesmo um diferente caráter prima facie entre regras e princípios, como sustentado por Alexy. ${ }^{25}$

23 Hart trata do tema trazendo um exemplo que envolve a noção de contrato válido. Ainda que preenchidas as condições positivas para a existência de um contrato válido, essas condições seriam apenas necessárias, mas não suficientes. Isso porque a alegação de que há um contrato válido pode ser derrotada em razão de inúmeras contingências. Essa ideia é traduzida por Hart pelo uso da expressão a menos que, relacionada à inclusão de exceções.

24 Para um estudo aprofundado sobre o tema, entre outros, cf. Brozek (2004).

25 Alexy (2011a, p. 103 ss.) afirma que as regras não têm sempre um mesmo caráter definitivo, como sustentado por Dworkin, isso porque em determinado caso pode haver a necessidade de se introduzir uma exceção à regra em virtude de um princípio. Ainda contrariando Dworkin, Alexy sustenta que essas possíveis cláusulas de exceção não são nem mesmo teoricamente enumeráveis, visto que um novo caso sempre poderá tornar necessária a inclusão de uma nova exceção. Em razão desses argumentos, afastando-se do modelo dworkiniano "simples", Alexy propõe um "modelo diferenciado", em que regras "perdem seu caráter definitivo estrito" quando há a inclusão da exceção principiológica. Entretanto, o caráter prima facie que "adquirem" 
No caso tratado, que envolve as regras sobre substituição presidencial, verifica-se que ao menos uma das normas não poderá ter todos os seus efeitos jurídicos ativados, ainda que preenchidos os seus pressupostos. O conflito irresolúvel determina a ponderação entre as regras, do que decorre sua derrotabilidade e a assunção de sua capacidade regulatória apenas prima facie.

(13) Assim, em face da situação concreta (5), são aplicáveis as normas (6) e (7), gerando um conflito (12) só solucionável por ponderação, do que resulta: definitividade (regulação prima facie). ${ }^{26}$

O fato de ser mais raro verificar-se um conflito de regras sujeito à ponderação quando é comparado com as colisões entre princípios não permite afirmar que as regras possuem comandos definitivos. Permite apenas dizer que o comando prima facie das regras se tornará

nesses casos - afirma - "é muito diferente daquele dos princípios". Enquanto, no caso dos princípios, um deles cede lugar simplesmente porque é conferido maior peso ao princípio antagônico, com as regras o fenômeno ocorreria de modo diferente. A regra não seria "superada pura e simplesmente quando se atribui, no caso concreto, um peso maior ao princípio contrário ao princípio que sustenta a regra”. Seria necessário também superar os princípios formais, aqueles que "estabelecem que as regras que tenham sido criadas pelas autoridades legitimadas para tanto devem ser seguidas”. Ou seja, os princípios formais protegeriam as regras, dando mais força a seu caráter prima facie quando estas são comparadas aos princípios. Entende-se, todavia, que o "modelo diferenciado" de Alexy parece não se sustentar por duas razões. A primeira é que não há que se falar em perda do caráter definitivo e aquisição de caráter prima facie. A própria caracterização de uma norma como prima facie diz sobre sua possibilidade de não regular de modo conclusivo, estando sujeita a não ter todos seus efeitos jurídicos ativados em função de possíveis conflitos com outras normas de sinal contrário. Reconhecendo-se que isso é possível, uma norma não deixa de ter um caráter definitivo para adquirir um caráter prima facie. As regras, portanto, não adquirem, mas possuem um caráter prima facie. E o mesmo vale para os princípios. No caso excepcional de não entrarem em conflito, sua regulação prima facie se tornará definitiva, mas isso não significa dizer que adquirem um caráter definitivo. Nesse sentido, mas referindo-se apenas ao caso das regras, cf. Lopes (2016, p. 125). A outra razão para infirmar o modelo diferenciado é a de que regras e princípios não possuem um diferente caráter prima facie. Como se pode perceber, o argumento utilizado para sustentar essa diferença baseia-se na força que a regra possui em função dos princípios formais quando em confronto com um princípio. Esse argumento, no entanto, desconsidera a possibilidade de um conflito entre regras que esteja sujeito à ponderação. Nesse caso, perde sentido a defesa de um caráter prima facie reforçado das regras em função dos princípios formais; eis que ambas as regras foram criadas pela autoridade legitimada e devem ser seguidas, fazendo que esses princípios atuem em ambos os lados do conflito e, portanto, que seus pesos se anulem. Nessas hipóteses, uma regra cederá lugar simplesmente porque é conferido maior peso à regra de sinal contrário, exatamente igual ao que ocorre com os princípios.

26 Com a mesma conclusão ao analisar o exemplo que envolve o conflito narrado entre as regras do sinal vermelho e das instalações militares, cf. Duarte (2012a, p. 529). 
definitivo em muito mais casos do que o comando prima facie dos princípios. A diferença, portanto, é apenas quantitativa, decorrendo da menor apetência conflitual das regras em relação aos princípios.

Dessa maneira, verifica-se que a derrotabilidade é uma característica de todas as normas, assim como sua capacidade regulativa prima facie. Logo, não é esse um critério de distinção satisfatório. ${ }^{27}$

\section{A SUbSUnÇÃO E A PONDERAÇÃo}

A subsunção e a ponderação são duas operações básicas de aplicação do Direito. ${ }^{\mathbf{2 8}} \mathrm{A}$ primeira pode ser representada por um esquema dedutivo; a segunda, por um esquema matemático, a fórmula do peso (ALEXY, 2003b, p. 433 ss.).

Como já visto, é lição clássica da teoria alexyana que as operações se inserem nos critérios distintivos; eis que as regras se aplicariam por subsunção e os princípios, por ponderação.

Não se pode, entretanto, concordar com essa afirmação. Isso porque: (i) como se viu, as regras aplicam-se por subsunção, mas também por ponderação; (ii) os princípios aplicam-se por ponderação, mas esta é precedida por uma subsunção; e (iii) os princípios, por vezes, aplicam-se unicamente por subsunção.

Assim, o critério é desde logo questionado pelo que já se demonstrou anteriormente, no sentido de que as regras também estão sujeitas à aplicação por meio da ponderação. Desde que determinada situação de fato preencha os pressupostos do antecedente de duas ou mais normas-regra que tenham efeitos incompatíveis e cujo conflito não seja solucionável por normas de prevalência, haverá necessariamente uma aplicação por ponderação. O exemplo clássico do sinal vermelho e das zonas militares, bem como aquele que envolve a substituição provisória da Presidência da República no Brasil, são suficientes para comprovar essa afirmação, razão pela qual é possível passar logo aos outros dois argumentos.

No que se refere aos princípios, não há dúvida de que possuem uma maior vocação ao conflito não solucionável por normas de prevalência, acarretando uma maior utilização da técnica da ponderação. É por meio dela que se verificará qual dos princípios envolvidos em determinado caso terá mais peso e, portanto, prevalecerá em sua solução. Contudo, como são selecionados os princípios que irão fazer parte dessa ponderação? Certamente, por meio

27 Nesse sentido e ressaltando a fragilidade da distinção qualitativa entre regras e princípios, cf. Brozek (2012, p. 220 ss.). Em uma perspectiva diferente, defendendo que apenas as regras são derrotáveis e que, assim, a própria derrotabilidade é um critério para diferenciar regras e princípios, cf. Bäcker (2011, p. 61 ss.).

28 Incluindo igualmente a comparação, ou analogia, ao lado da subsunção e da ponderação, como as três operações básicas de aplicação do Direito, entre outros, cf. Alexy (2010, p. 9 ss.). 
de uma prévia subsunção (DUARTE, 2012a, p. 530-532; BROZEK, 2007, p. 104-115). Dessa forma, por meio da ponderação, o juiz definirá qual princípio terá maior peso, mas ele não é livre para escolher os princípios que irá colocar na balança. Não há como ponderar sem antes identificar os enunciados normativos prima facie aplicáveis de acordo com o enquadramento dos fatos relevantes do caso e determinar seus significados (determinação semântica das normas), ${ }^{29}$ bem como verificar os eventuais conflitos normativos existentes, em típica atividade dedutiva.

Somente após a constatação de que os fatos preenchem o antecedente de mais de um princípio - a aplicação das normas de prevalência (DUARTE, 2006, p. 153 ss.) - e a verificação de que ainda restam princípios com efeitos conflitantes é que se torna possível e necessária a ponderação. O processo ponderatório, como operação de aplicação do Direito, nada diz sobre essa atividade anterior, que é necessária e de natureza subsuntiva. A ponderação é, portanto, uma operação subsequente ${ }^{30}$ e subsidiária em relação à subsunção, que, por sua vez, está presente em todos os casos (DUARTE, 2015, p. 2), seja na aplicação de regras, seja na de princípios. Utilizando-se o conhecido caso que envolve o fornecimento de medicamentos não aprovados pela Anvisa ${ }^{31}$ e as normas da Constituição brasileira, pode-se ilustrar o afirmado:

(14) Se há uma pessoa com doença grave requerendo ao Estado brasileiro um medicamento experimental e não aprovado pela Anvisa para o tratamento indicado.

(15) Antes da subsunção, não há como saber quais normas aplicar.

(16) Após a seleção dos enunciados normativos convergentes ao caso e a determinação de seus significados, tem-se: $\mathrm{N}^{1}=\mathrm{P}$ : o Estado deve fornecer medicamentos (direito fundamental à saúde, em sua dimensão prestacional, extraído do enunciado do art. 96); $\mathrm{N}^{2}=\mathrm{P}$ : o Estado deve garantir a vida das pessoas (direito fundamental à vida, extraído do art. $5^{\circ}$ ); $\mathrm{N}^{3}=\mathrm{P}$ : o Estado deve garantir a segurança dos medicamentos (direito fundamental à saúde, em sua dimensão de proteção, extraído do art. 200, incisos I e II).

Sobre a determinação semântica das normas como primeira fase do processo de formulação de uma norma de decisão, cf. Duarte (2006, p. 168 ss.).

30 Conforme Duarte (2012a, p. 531), a ponderação surge depois, no plano da meta-subsunção. Para Brozek (2007, p. 114), a fórmula de peso (e a ponderação, portanto) desempenha o seu papel no segundo nível de argumentação, no nível em que os argumentos extraídos dos princípios são comparados, e não no primeiro nível, em que esses argumentos são construídos.

31 Anvisa é a Agência Brasileira de Vigilância Sanitária, responsável por analisar a efetividade e a segurança dos medicamentos, aprovando-os para comercialização no país. Esse exemplo foi retirado de trabalho que aborda justamente a necessidade de realização da subsunção prévia em oposição à livre escolha dos princípios sujeitos à ponderação, em uma análise da jurisprudência brasileira. Com maiores desenvolvimentos, cf. Sacramento (2017, p. 374 ss.). 
(17) Identificando a concorrência de normas e aplicando as normas de prevalência (princípio da especialidade, isso considerando que, nesse caso, a norma do direito à saúde - dimensão prestacional - está em uma relação de especialidade declarativa em relação ao direito à vida ${ }^{32}$ ), ocorre a configuração final do conflito com a seleção das normas que estarão sujeitas à ponderação: $\mathrm{N}^{1} \mathrm{e} \mathrm{N}^{3}$.

(18) A ponderação resolverá o conflito de acordo com os pesos atribuídos a cada princípio. ${ }^{33}$

Por fim, há casos em que os princípios são aplicados exclusivamente por subsunção. $\mathrm{O}$ ato de publicar um artigo que não fere o direito à vida privada de ninguém, ou outro direito fundamental, é garantido pelo princípio que assegura a liberdade de expressão, ${ }^{34}$ aplicado por subsunção, sem necessidade de realizar-se uma ponderação. Verificada a inexistência de colisão com outros princípios, o comando prima facie se tornará definitivo, com base na subsunção que se mostrou suficiente para solucionar o caso.

Como se vê, a subsunção é a primeira técnica necessariamente utilizada para resolver determinado problema jurídico. Em alguns casos, ela será suficiente. Em outros, porém, a identificação de um conflito normativo não solucionável por normas de prevalência exigirá que o juiz faça uso também da técnica subsidiária da ponderação.

A forma de aplicação das normas decorre, então, da eventual identificação de um conflito irresolúvel, e não de sua eventual caracterização como regra ou princípio. Ambos se aplicam de igual forma. ${ }^{35}$

Simplificadamente, o direito fundamental à saúde impõe ao Estado o dever de garantir a saúde das pessoas por meio de prestações, para tratamento das doenças menos ou mais graves, incluindo as que coloquem em risco a vida das pessoas. Não parece fazer sentido a interpretação de que a norma que garante o direito à saúde só se aplica aos casos de doenças menos graves. Aceitando-se essa premissa, quando o risco à vida é decorrência de problemas de saúde, a norma que garante o direito à saúde é claramente especial em relação ao direito à vida, ainda que em relação de especialidade declarativa, porquanto, no caso, ambas impõem ao Estado o mesmo dever. Embora possa haver algo de polêmico no exemplo, entende-se que, de qualquer forma, ele é suficientemente claro para o que se pretende demonstrar.

33 É importante registrar que nesse específico caso o legislador já resolveu o conflito, proibindo como regra geral o fornecimento de medicamento não aprovado pela Anvisa (art. 19-T da Lei n. 8.080/1990) e permitindo, excepcionalmente, o fornecimento de um medicamento experimental para tratamento do câncer (fosfoetanolamina sintética - arts. $2^{\circ}$ e $4^{\circ}$ da Lei n. 13.269/2016). Nada impede, contudo, a análise dessas normas e sua eventual declaração de inconstitucionalidade ou a realização de uma interpretação conforme. A última norma, aliás, está com a eficácia suspensa em função de liminar proferida pelo STF (ADI n. 5.501).

34 O exemplo é de Aarnio (1997, p. 23 e 25), que o utiliza no contexto daquilo que chama de "princípios que são como regras".

35 Ralf Poscher critica o "erro metodológico" da teoria dos princípios ao vincular as regras ao processo de subsunção e os princípios ao processo de ponderação. Para o autor, a utilização de ambas as técnicas de aplicação 


\section{A dimensão de PeSO}

A possibilidade da existência de conflitos de regras solucionáveis unicamente por ponderação evidencia ainda outra incongruência da teoria dominante. O fato é que, nesses casos, o conflito entre regras ocorre na dimensão do peso. Assim, ao contrário do que é em geral afirmado, o conflito entre essas regras não ocorre apenas na dimensão da validade, mas também na dimensão do peso.

No caso do conflito entre as normas-regra que envolve a substituição do presidente, deve-se ser feita uma ponderação ${ }^{36}$ nos mesmos moldes da realizada entre princípios, devendo a decisão ser tomada com base no peso atribuído a cada regra em função das circunstâncias do caso concreto. Nesse caso, portanto, não há que se falar em dimensão da validade. Uma das duas normas terá apenas que ceder, ainda que parcialmente, em função dos pesos atribuídos. Nem a regra que estabelece o rol de substitutos e a ordem de nomeação nem a regra que proíbe a nomeação de substitutos que forem réus serão declaradas inválidas. ${ }^{37}$

\section{OS MANDAMENTOS DE OTIMIZAÇÃO}

Além do desenvolvimento das ideias de Dworkin, a principal inovação trazida por Alexy na distinção qualitativa entre regras e princípios foi a introdução do conceito de princípios como mandamentos de otimização.

Assim, os princípios seriam normas que ordenam que algo seja realizado na maior medida possível dentro das alternativas jurídicas e fáticas existentes. O âmbito das possibilidades

do direito não se vincula às espécies normativas, mas depende da riqueza das situações de fato ou dos estados de coisas que são trazidos à consideração. Para cada norma, podem existir casos fáceis, em que basta seguir a regra aplicada por subsunção, ou casos difíceis, em que são necessárias outras reflexões, argumentações e, em algumas situações, ponderações. Assim, embora não exatamente com os mesmos fundamentos aqui apresentados, o autor alemão defende que a subsunção e a ponderação não servem para identificar regras ou princípios, pois ambos podem ser aplicados pelas duas técnicas (POSCHER, 2011, p. 82-85). Aliás, a manutenção da afirmação por parte de Alexy de que as regras se aplicam por subsunção e os princípios, por ponderação parece ter fins apenas didáticos ou de simplificação. Isso, porque o autor reconhece que a subsunção está presente na aplicação dos princípios, tanto antes quanto depois da ponderação. Depois, no sentido de que após a ponderação entre dois princípios, em que há a precedência de um sobre outro em determinadas circunstâncias do caso, de acordo com a lei da colisão, extrai-se uma regra que será então subsumida ao caso concreto (ALEXY, 2010, p. 11).

36 Tal tarefa caberia ao Congresso Nacional (art. 78 da Constituição), mas estaria sujeita à análise de sua proporcionalidade, como será visto na sequência.

37 Reconhecendo que também as regras possuem uma dimensão de peso e que, portanto, esse não é um critério idôneo para fundamentar uma distinção qualitativa entre regras e princípios, cf. Pino (2010, p. 56-57). Também nesse sentido, cf. Ávila (2014, p. 74 ss.). 
jurídicas é determinado pelos princípios e regras colidentes. São caracterizados, dessa forma, pela possibilidade de "satisfação em graus variados", limitados, portanto, pelas normas de sinal contrário (ALEXY, 2011a, p. 90).

As regras, no caminho inverso, já conteriam "determinações no âmbito do que é fática e juridicamente possível" (ALEXY, 2011a, p. 91). Seriam satisfeitas ou não satisfeitas. "Se uma regra vale, então, deve se fazer exatamente aquilo que ela exige; nem mais, nem menos" (ALEXY, 2011a, p. 91). As regras, portanto, não poderiam ser aplicadas de forma gradual.

A otimização em relação às possibilidades jurídicas determinadas pelos princípios colidentes é, segundo Alexy, expressada pelo princípio da proporcionalidade em sentido estrito terceiro subprincípio do princípio da proporcionalidade. Seu significado seria idêntico ao da lei da ponderação: "Quanto maior for o grau de não satisfação ou de afetação de um princípio, tanto maior terá que ser a importância da satisfação do outro” (ALEXY, 2011a, p. 167).

Antes de chegar ao terceiro subprincípio, pode haver a otimização das possibilidades fáticas, de modo a evitar custos ou interferências nos princípios envolvidos. Se foi necessário realizar a ponderação, é porque os custos são inevitáveis e serão suportados pelos princípios colidentes. Será preciso, então, otimizar as possibilidades jurídicas, por meio de atribuição de pesos. Assim, “a otimização com relação aos princípios colidentes nada mais é que o sopesamento" (ALEXY, 2011a, p. 594; ALEXY, 2003a, p. 136).

A ponderação, dessa forma, é um meio comparativo e otimizador dos princípios colidentes no que se refere às possibilidades jurídicas, estabelecendo uma espécie de concordância prática ${ }^{38}$ entre eles e afastando, porque desproporcionais, as decisões que não os apliquem de maneira ótima. Essa operação jurídica comparativa pode ser racionalmente explicada por meio da fórmula do peso. ${ }^{39}$

Entende-se que toda a metodologia alexyana para a ponderação de princípios é aplicável à ponderação de regras. Do mesmo modo, então, o sopesamento também significará a otimização das regras, devendo ambas ser aplicadas em seu grau máximo, de acordo com as possibilidades jurídicas. E isso parece ser suficiente para caracterizá-las como mandamentos de otimização.

O afirmado fica ainda mais claro quando se verificam exemplos que facilitam a identificação da aplicação de maneira gradual e otimizadora (no sentido de "não integral" ou "no máximo possível”) também das regras. A análise do caso da substituição da Presidência da República

Para Alexy, do conceito de princípio decorre a noção de que os sopesamentos "não são uma questão de tudo ou nada, mas uma tarefa de otimização". Assim, o modelo de sopesamento defendido por Alexy seria "equivalente ao assim chamado princípio da concordância prática” (ALEXY, 2011a, p. 173).

39 Desnecessário, aqui, adentrar nas especificações de suas variáveis e no funcionamento da fórmula aritmética. Cf., por exemplo, Alexy (2011a, p. 604 ss.). Para sua última versão, a "fórmula do peso completa e refinada”, cf. Alexy (2014, p. 514-515). 
ajuda a demonstrar também esse ponto. Para facilitar, é conveniente trazer novamente o caso e as normas em conflito:

(19) Se há necessidade de convocar um substituto presidencial em razão de dupla vacância ou duplo impedimento, mas todos eles são réus no STF.

(20) $\mathrm{N}^{1}=\mathrm{R}$ (quando há dupla vacância ou duplo impedimento, é obrigatório chamar ao exercício da presidência os titulares dos seguintes cargos, nesta ordem: o presidente da Câmara, o do Senado e o do STF).

(21) $\mathrm{N}^{2}=\mathrm{R}$ (se o presidente da Câmara, o do Senado e o do STF forem réus no STF, é proibido chamá-los ao exercício da Presidência da República).

Diante do caso, será necessário tomar uma decisão e ela deverá ser proporcional, otimizando-se os efeitos das normas colidentes.

Primeiro, é preciso considerar que ambas as normas possuem grande importância e um idêntico peso abstrato. A N ${ }^{1}$ (20) estabelece quem deve temporariamente presidir o país em determinadas situações. Elenca, dentro de uma ordem de preferência, as autoridades que presidem os órgãos máximos dos demais poderes. A regra, portanto, tem ligação com o sistema presidencialista, com o regime democrático e com a separação de poderes. Não é por outra razão que não inclui outras autoridades. Estabelece que o primeiro é o presidente do órgão que representa o povo (Câmara dos Deputados), o segundo é o do órgão que representa os Estados (Senado Federal), e o terceiro, único não eleito pelo voto popular, é o presidente do STF, órgão de cúpula do Judiciário.

Já a $\mathrm{N}^{2}$ (21) tem a importante finalidade de garantir a "respeitabilidade das instituições da República e a própria dignidade institucional do ofício presidencial”, ${ }^{40}$ impedindo o exercício por aqueles que, por sua condição pessoal de réus no STF, não cumpram a exigência. A regra é igualmente importante para que haja uma equivalência entre a restrição ao direito do presidente eleito e a restrição ao direito dos substitutos. É que, do mesmo texto legal (art. 86, $\S 1^{\circ}$ ), é extraída a norma que suspende cautelarmente o presidente eleito quando ele se torna réu. Não cumprir referida norma, de algum modo, dá mais poder aos substitutos eventuais do que ao presidente eleito.

Diante disso, é o grau de interferência e a importância da satisfação das regras, de acordo com as circunstâncias do caso concreto, que serão decisivos nessa ponderação. E, nesse sentido, várias espécies de argumentos e circunstâncias poderão ser levadas em conta. Nessa escolha, tendo em vista a finalidade e a determinação contida em cada norma, parece que, entre outros,

40 Nas palavras do ministro Celso de Mello, proferidas em seu voto no julgamento do pedido liminar da ADPF n. 402 (disponível em: http:/ / portal.stf.jus.br/processos/detalhe.asp?incidente=4975492; acesso em: 11 jun. 2019 ). 
podem ser considerados os seguintes elementos: (i) a ordem que o indicado ocupa na lista de preferência; (ii) a gravidade e a natureza do delito de que é acusado; (iii) a fase processual do processo criminal de cada legitimado. ${ }^{41}$

Levando-se em conta esses elementos, pode-se enriquecer o exemplo, supondo que o presidente da Câmara (PC), o presidente do Senado (PS) e o presidente do STF (PSTF) são réus e acusados de terem cometido os seguintes crimes, na seguinte fase processual:

(22) (PC), crimes de corrupção passiva, associação criminosa e homicídio, já condenado a 30 anos de prisão, aguardando julgamento de recurso.

(23) (PS), crime de lesão corporal culposa, sujeito a pena máxima de 1 ano, com processo na fase inicial, apenas recebida a denúncia.

(24) (PSTF), de modo idêntico ao (23), crime de lesão corporal culposa, sujeito a pena máxima de 1 ano, com processo na fase inicial, apenas recebida a denúncia.

Considerando-se essas hipotéticas circunstâncias fáticas e as possibilidades jurídicas, bem como garantindo-se que a interferência em uma das regras seja justificada na medida da satisfação de outra, a única decisão que parece obedecer à proporcionalidade é o chamamento do PS, o segundo na lista de prioridade determinada pela $\mathrm{N}^{1}$ (20).

A preterição do PC se explica em razão de que a importância da não afetação de $\mathrm{N}^{1}$ (20), no que se refere exclusivamente a sua ordem de preferência, parece não justificar a intensidade da interferência com $N^{2}$ (21). É, portanto, em razão dos efeitos de $\mathrm{N}^{2}$ (21) que não deve ser escolhido o primeiro da lista (PC).

Por conta dos efeitos de $\mathrm{N}^{1}$ (20), entretanto, por seu rol de preferência, é que se justifica a escolha do segundo (PS), e não do terceiro (PSTF). Nesse caso, é possível otimizar os efeitos de $\mathrm{N}^{1}$ (20), respeitando sua ordem de prioridade, sem prejudicar a posição de $\mathrm{N}^{2}(21)$; eis que o grau de interferência será o mesmo.

Pelo que se entende, nessas circunstâncias fáticas, seria difícil justificar racionalmente a escolha de outros legitimados sem ferir o princípio da proporcionalidade.

Como se vê, as normas tiveram parte de seus efeitos aplicados. A aplicação na forma do tudo ou nada, absoluta, implicaria a nomeação do PC em todos os casos - obedecendo integralmente à $\mathrm{N}^{1}(20)$-, ou o impedimento da nomeação de todos os substitutos em todos os casos - optando-se por $\mathrm{N}^{2}(21) .^{42}$

41 Aqui se pode ter em conta a natural tensão da $\mathrm{N}^{2}$ (21) com a garantia da presunção de inocência.

42 Nesse caso, haveria o conflito com a norma que estabelece o regime presidencialista, exigindo a nomeação de um presidente. Entretanto, a nomeação de uma pessoa estranha à lista dos substitutos, o que contraria os critérios estabelecidos, parece não ser uma solução constitucionalmente possível. 
Assim, no que se refere às possibilidades jurídicas, tanto regras quanto princípios devem ser otimizados. Ao contrário do defendido por Alexy, parece não haver possibilidades de as regras já possuírem uma determinação do que é juridicamente possível, pois isso só se é capaz de saber após tudo considerado, após a identificação dos possíveis conflitos normativos. O exemplo mostra que, ainda que dentro de limites mais determinados, em caso de conflito, as regras - ao menos essas do exemplo - podem, sim, ser aplicadas de maneira mais ou menos, do mesmo modo que os princípios.

A determinação de que algo seja realizado na maior medida possível em função das alternativas jurídicas é característica de todas as normas - regras ou princípios -, pois está ligada à possibilidade de conflito com as normas de sinal contrário, e não com a eventual diferença estrutural entre as espécies normativas. ${ }^{43}$

\section{I. MAndamentos a SEREM Otimizados E O "DEVER IDEAL"}

A distinção delimitada por Alexy, com base na ideia de princípios como mandamentos de otimização, recebeu importantes críticas. Aarnio (1997, p. 27), por exemplo, apontou que a identificação dos princípios com os mandamentos de otimização não é correta, porquanto a obrigação de otimizar tem um caráter definitivo, pode ser ou não cumprida, e não pode ser satisfeita em variados graus. O mandamento de otimização, assim, teria um caráter de regra.

Alexy acolheu as críticas e promoveu um refinamento em sua teoria (ALEXY, 2000, p. 300-301), passando a defender que os princípios não seriam mandamentos de otimização, mas "mandamentos a serem otimizados". Assim, nessa segunda versão, os princípios passam a ser o objeto da otimização e os mandamentos de otimização estariam em um metanível. Alexy passou a defender também que a diferença entre princípios e regras pode ser vinculada às ideias de "dever ideal" e "dever real". Os princípios, ou mandamentos a serem otimizados, expressam um dever ideal, um dever prima facie a ser cumprido o máximo possível e que se transformaria em um dever real por meio da otimização. O dever ideal, assim, implicaria o mandamento de otimização, e vice-versa. No entanto, as regras representariam um dever real, um dever definitivo que só pode ser cumprido ou descumprido.

Após novas críticas a esse refinamento (POSCHER, 2011), Alexy (2011b e 2017) desenvolveu sua ideia e esclareceu que a diferença entre dever ideal e dever real reflete na diferença entre duas modalidades deônticas, que podem ser expressas da seguinte forma: $\mathrm{O}_{\mathrm{i}}$ p. (dever ideal) e $\mathrm{O}_{\mathrm{r}}$. (dever real).

43 Considerando que o conceito de mandamento de otimização é aplicável também às regras com base em um exemplo de conflito entre uma regra e um princípio, cf. Brozek (2012, p. 223). Aliás, com base nessas e em outras considerações, o autor refuta os critérios defendidos por Alexy e reflete que não há um critério seguro para a distinção entre regras e princípios. 
Tais modalidades corresponderiam à reconstrução formal da diferença entre princípios e regras. O dever ideal não levaria em conta eventuais deveres contrários, não estando ainda relacionado com as possíveis limitações normativas, e, portanto, seria um dever apenas prima facie. Já o dever real, ao contrário, seria um dever que já levaria tudo em consideração, sendo, portanto, um dever definitivo.

Essa evolução da teoria alexyana tem recebido novas críticas ${ }^{44} \mathrm{e}$, da mesma forma que a versão anterior, não constitui um critério adequado para diferenciar regras e princípios.

Pelo que já foi exposto, não é possível considerar que as regras expressem um dever real, definitivo, que já considere todas as circunstâncias em sentido contrário. As regras também possuem deveres apenas prima facie. Isso ficou claro na análise do exemplo que envolve as normas que tratam da substituição da Presidência da República. As propriedades relevantes do caso podem acionar os antecedentes de duas regras com consequências jurídicas incompatíveis. Assim, ao contrário do que defende Alexy (2017, p. 10-11), é possível uma contradição de normas-regra no nível ideal, em que as duas normas mantêm sua validade, e o dever real só é obtido a partir da resolução do conflito na dimensão do peso, realizando-se a otimização por meio da ponderação.

Já a consideração dos princípios como objetos de mandamentos de otimização parece gerar problemas ainda maiores. Ao menos três deles podem ser facilmente apontados.

Em primeiro lugar, como já foi visto, as regras podem envolver-se em conflitos normativos sujeitos à ponderação, com o consequente dever de otimização em relação às possibilidades jurídicas.

Em segundo lugar, se os princípios são as normas sobre as quais incide uma meta-regra implícita de otimização, a diferença entre princípio e regra não estaria na norma a ser otimizada, mas na existência ou não da meta-regra de otimização. Seria possível concluir, então,

44 Poscher (2011, 2012 e 2015) apresentou uma série de objeções à teoria dos princípios, inclusive sobre o refinamento apontado por Alexy. Não é possível reproduzi-las aqui, mas importa registrar que, para o autor, tendo em conta as acertadas e acolhidas críticas que envolvem os mandamentos de otimização, conceito que tentava explicar o fenômeno normativo no âmbito da teoria alexyana, a teoria dos princípios teria perdido seu objeto, e a introdução do conceito de "dever ideal" seria apenas uma tentativa de dissimular essa perda. Além disso, a reconstrução da ideia de princípios como mandamentos a serem otimizados falharia ao considerar que o objeto da otimização seria uma norma. Ao contrário, os mandamentos de otimização se dirigem a objetos fáticos. Nesse sentido, por exemplo, os mandados de otimização buscariam o aperfeiçoamento da liberdade de expressão, e não do mandamento da liberdade de expressão. Em seu último trabalho sobre o tema, Alexy (2017, p. 20) reconhece a correção do argumento, esclarecendo que o objeto da otimização é idêntico ao objeto do dever ideal, um estado de coisas em sentido amplo (p.). Assim, alterando a posição anterior, ele esclarece que a notação correta para essa estrutura é “O Opt p.”, e não "O Opt Op.”. Aliás, a estrutura lógica dos princípios na teoria de Alexy, especialmente no que se refere à função lógica do elemento "Opt", também tem recebido objeções. Nesse sentido, cf. Alonso (2016). 
que todas as normas consideradas individualmente são regras, sendo consideradas princípios apenas quando vinculadas a eventual meta-regra de otimização, o que evidencia a impropriedade do critério de distinção (RAMIÃO, 2018, p. 166-167; ZORRILLA, 2018, p. 175).

Em terceiro lugar, pode-se fazer a crítica da tautologia. Se otimizar, a rigor, significa efetivamente aplicar a norma ao máximo de situações nas quais as suas condições de aplicação são preenchidas, a otimização não seria nada mais do que a obrigação de aplicar uma norma quando ela é considerada aplicável, o que seria inerente a todas as normas, mostrando-se desnecessária a existência de uma meta-regra de otimização para que ocorra esse efeito (RAMIÃO, 2018, p. 167-168; ZORRILLA, 2018, p. 176).

\section{REGRAS E PRINCÍPIOS EM UM BALANÇO FINAL}

\section{I. DIFERENÇA ENTRE REGRAS E PRINCÍPIOS: A INSUFICIÊNCIA DOS CRITÉRIOS E A ORIGEM} DOS SINTOMAS

Todos os critérios analisados até agora parecem não estabelecer uma segura distinção entre regras e princípios.

Pode-se dizer, entretanto, que todos são sintomas de alguma diferença, eis que aparecem predominantemente mais em uma espécie do que na outra. Comparando-se com as regras, é possível afirmar, por exemplo, que os princípios se aplicam mais por ponderação; que são mais derrotáveis e que, portanto, sua regulação prima facie menos vezes se torna definitiva; que é mais comum e mais fácil observar a aplicação gradual em razão das possibilidades jurídicas.

Tais fatores, na verdade, não representam um critério que demonstre uma diferença estrutural de regras e princípios, mas apenas sintomas decorrentes de um único fenômeno: os conflitos normativos. Pondera-se quando há um conflito irresolúvel por normas de prevalência. Uma norma é derrotada sempre em razão do conflito com outra norma de sinal contrário. Regras e princípios são mandamentos de otimização dentro das possibilidades jurídicas e podem ser aplicados em graus justamente porque seus limites são estabelecidos por normas de sinal contrário, em um contexto de conflito normativo.

Os princípios, no entanto, possuem uma maior apetência conflitual. Assim, o fato de serem mais comumente derrotáveis, ponderáveis e otimizáveis não decorre diretamente de sua estrutura diferente, mas de seu maior envolvimento em conflitos normativos. Isso não impede, por sua vez, a constatação de que ainda restam diferenças de comportamento e de estrutura entre as duas espécies normativas, o que será analisado nos próximos tópicos.

\subsection{A DIFERENÇA COMPORTAMENTAL - INDETERMINAÇÃO E EXPANSIVIDADE: OS PRINCÍPIOS} COMO MANDAMENTOS DE MAXIMIZAÇÃO

Se os sintomas não decorrem do fato de uma norma ser regra ou princípio, mas em função do conflito em que eventualmente esteja envolvida, uma possível distinção entre as espécies 
normativas só tem como ser identificada em uma análise individual das normas, e não no contexto de todo ordenamento jurídico, quando os conflitos se revelam.

E, nessa perspectiva, pode-se apontar inicialmente a existência de uma diferença comportamental: há uma expansividade, uma projeção dos princípios sobre o mundo dos fatos que não está presente nas regras. Essa expansividade implica que, prima facie, o princípio abranja todas as ações humanas e estados de coisas possíveis, considerando-se apenas as possibilidades fáticas. Nesse prisma, os princípios podem ser identificados como mandamentos a maximizar ou, simplificadamente, mandamentos de maximização. ${ }^{45}$

Dessa expansividade resultante do mandamento de maximização decorre, por exemplo, o entendimento de que, prima facie, desde condutas como publicar um artigo ou dar uma entrevista, até condutas como agressões racistas ou antissemitas, sejam abrangidas pelo princípio da liberdade de expressão. O mandamento de maximização determina a projeção máxima e gradual de um princípio sobre ações humanas e estados de coisas possíveis de ocorrência no mundo dos fatos, indicando a aplicabilidade da norma e a abrangência de seus comandos prima facie.

A necessidade de maximização decorre de uma característica específica dos princípios: a indeterminação. Nessa espécie normativa, não é possível identificar previamente a quais situações da vida a norma se aplica, ${ }^{46}$ o que só se torna possível por meio da maximização. Isso pode ser identificado no exemplo a seguir:

(25) É garantida a liberdade de expressão.

(26) Há extrema indeterminação. Só se consegue saber o âmbito de aplicação da norma por meio da maximização sobre todas as ações humanas e estados de coisas que ensejarão sua aplicação.

Com as regras é diferente. Seus pressupostos de aplicação são determinados. É possível saber previamente as situações da vida que acionam seus efeitos, sem necessidade de maximizar:

(27) Se houver dupla vacância ou duplo impedimento, é obrigatório chamar os substitutos na seguinte ordem: o presidente da Câmara, o do Senado e do STF.

45 Como se verá a seguir, a nomenclatura foi utilizada por Robert Alexy para explicar algo muito semelhante (ALEXY, 2011a, p. 95). A intenção é diferenciar os mandamentos de maximização, característica dos princípios, dos mandamentos de otimização, característica presente em todas as normas. Essa diferença será abordada no tópico seguinte.

46 Alexy (2011a, p. 99) refere que é da natureza dos princípios (como mandamentos de otimização) "sua referência a ações e situações que não são quantificáveis”. 
Fica claro que a regra se aplica para o caso de ocorrer dupla vacância ou duplo impedimento. Há determinação sobre a quais situações fáticas a norma se aplica. Não há maximização e expansividade. Previamente, é possível saber que, se um desses fatos - e apenas esses ocorrer, há incidência da norma, implicando a ativação de todos os seus comandos prima facie: chamamento dos substitutos na ordem estabelecida.

Assim, como mandamentos de maximização, os princípios possuem comandos prima facie progressivos sobre o mundo dos fatos, enquanto as regras possuem comandos prima facie estáticos. As diferenças de característica e de comportamento entre regras e princípios, quando analisadas individualmente, antes de se levar em consideração eventuais conflitos, são:

(28) $\mathrm{R}=$ (determinação), (expansividade).

(29) $\mathrm{P}=$ (indeterminação), (expansividade).

\subsection{Mandamentos de maXimizaÇÃo e mandamentos de otimização}

Adotar a proposta defendida de princípios como mandamentos de maximização exige a clara diferenciação entre mandamentos de maximização e mandamentos de otimização, bem como um ajuste neste último conceito.

Para Alexy, o "ponto decisivo” na diferença entre as espécies normativas é que princípios são mandamentos de otimização, ${ }^{47}$ "normas que ordenam que algo seja realizado na maior medida possível dentro das possibilidades jurídicas e fáticas existentes” (ALEXY, 2011a, p. 90), e o conceito considera a conexão e as colisões com as demais normas do ordenamento jurídico (ALEXY, 2011a, p. 95). Assim, a otimização engloba os dois conceitos que, simplificadamente, podem ser identificados como: otimização jurídica e otimização fática.

Já o conceito aqui defendido de princípios como mandamentos de maximização, por sua vez, refere-se apenas às possibilidades fáticas, em uma análise que leva em conta o princípio isoladamente considerado. ${ }^{48} \mathrm{Com}$ isso, considerando o exposto e o que se viu sobre a expansividade e a indeterminação dos princípios, bem como fazendo o ajuste necessário, é possível concluir que:

$47 \mathrm{Ou}$, com as especificações já analisadas, "mandamentos a serem otimizados". Por simplificação, Alexy (2014, p. 515) segue utilizando a expressão "mandamentos de otimização” em suas publicações.

48 É reveladora a afirmação de Alexy (2011, p. 95) no sentido de que, deixando-se de lado as eventuais colisões, "a referência às possibilidades jurídicas perde seu significado [...]. De mandamento de otimização, o princípio seria transformado em mandamento de maximização relativo apenas às possibilidades fáticas. Isso conduz à ideia geral segundo a qual os princípios, se isoladamente considerados - isto é, independentemente de sua relação com outros princípios -, tem natureza de mandamentos de maximização”. Dessa maneira, a rigor, o critério aqui colocado não destoa totalmente do proposto por Alexy. Trata-se, na verdade, de uma cisão que procura manter como critério de distinção a única característica que se entende estar presente exclusivamente nos princípios. 
(30) Princípios e regras são mandamentos de otimização jurídica.

(31) Apenas princípios são mandamentos de otimização fática, por isso identificados como mandamentos de maximização.

\subsection{A diferença estrutural: o anteCedente normativo e os Pressupostos disjuntivos E INCLUDENTES}

Tendo em conta o exposto no tópico anterior, resta saber a razão da maior expansividade e da indeterminação dos princípios. Com base em David Duarte (2012b, p. 51 ss.), pode-se afirmar que tais características decorrem da diferença estrutural em um dos elementos das normas: o antecedente. ${ }^{49}$

No caso dos princípios, há uma indeterminação das ações humanas e dos estados de coisas previstos no antecedente das normas. ${ }^{\mathbf{5 0}} \mathrm{O}$ antecedente contém uma extensão ilimitada de condições disjuntivas, e a ocorrência de qualquer uma delas é suficiente para ativar a consequência da norma. Essa indeterminação implica certa continuidade, no sentido de que as condições abarcam ações humanas em todas as suas formas e todos os tipos distintos de exercício, havendo um movimento progressivo em direção a uma parcela cada vez maior do mundo dos fatos capaz de ativar a consequência normativa.

É o que ocorre no caso do princípio da liberdade de expressão. Em um primeiro momento, não é possível identificar seu âmbito de aplicação. Só a partir da projeção maximizada da norma sobre o mundo dos fatos é possível identificar suas condições de aplicabilidade que são capazes de, por si só, ativar seu efeito jurídico. Por isso, há uma expansividade de regulação prima facie.

E, como essa projeção maximizada é propriedade de todos os princípios, é evidente que inúmeras situações da vida acabam preenchendo as condições de aplicabilidade de mais de um princípio, muitas vezes com efeitos incompatíveis, o que explica sua maior apetência conflitual.

49 Importa registrar que se subscreve integralmente à construção do autor que, como se verá logo a seguir, explica a distinção estrutural entre regras e princípios em razão das diferenças existentes no antecedente das normas (determinação ou indeterminação das ações humanas e dos estados de coisas previstos) e sua relação com as condições disjuntivas e a expansividade no que se refere aos princípios. A única ressalva necessária, porém, é que neste trabalho se utiliza essa construção para a defesa da ideia de princípios como mandamentos de maximização e seus desenvolvimentos, o que não é sustentado pelo autor.

50 Essa indeterminação independe da existência de termos vagos ou de qualquer incerteza semântica no enunciado normativo (DUARTE, 2012b, p. 57). Ao contrário, a indeterminação está ligada à genericidade da conduta prevista no antecedente dos princípios. No exemplo do antecedente da liberdade de expressão, na ação genérica de expressar-se, há uma inicial indeterminação das ações autônomas específicas que são capazes de acionar os efeitos da norma e que, portanto, estão prima facie protegidas. Especificamente sobre a genericidade, cf. Lopes (2017, p. 280-287). 
Já no antecedente das regras, não há essa indeterminação das ações humanas e dos estados de coisas. Mesmo que haja condições disjuntivas, elas são limitadas, e cada uma especifica um domínio preciso (DUARTE, 2012b, p. 56). Não há expansividade, diminuindo a chance de ocorrência de conflitos.

Essas diferenças estruturais no antecedente das normas permitem entender a distinção entre regras e princípios. Por elas, portanto, é possível explicar o comportamento expansivo e gradual sobre o mundo dos fatos que está presente unicamente nos princípios e que possibilitam, assim, caracterizá-los como mandamentos de maximização.

\section{CONCLUSÃO}

A partir do exemplo que envolve a substituição do presidente da República no Brasil, verificou-se que há conflitos entre regras que são resolvidos da mesma forma que a colisão entre princípios: pela ponderação.

A ponderação, assim, configura-se como a técnica de resolução de conflitos normativos não solucionáveis por normas de resolução de conflito (prevalência da norma posterior, da especial e da superior), independentemente da espécie normativa - regras ou princípios. A ponderação tem lugar quando o sistema não oferece a solução. Nesse sentido, apresenta-se como uma inevitabilidade.

Isso demonstra que tanto regras quanto princípios são derrotáveis e, portanto, possuem um caráter prima facie. As regras não têm comandos definitivos, ou aplicação tudo ou nada.

Além disso, a subsunção e a ponderação são duas das três operações básicas de aplicação do direito. Regras e princípios são aplicadas por subsunção e, subsidiariamente, por ponderação.

Ademais, como se viu, regras e princípios são mandamentos de otimização, considerando-se as possibilidades jurídicas. Com isso, os critérios utilizados para a defesa da distinção qualitativa entre regras e princípios com base nas teorias de Dworkin e Alexy não parecem ser suficientemente seguros.

Vários dos sintomas da diferença entre as espécies normativas que em geral são associados aos princípios (ponderação, derrotabilidade, caráter prima facie, otimização) decorrem, na verdade, exclusivamente do fenômeno dos conflitos normativos. Os princípios, entretanto, entram mais vezes em conflito e, por isso, apresentam com mais frequência essas características.

Se todos os sintomas decorrem do conflito normativo, a única alternativa para diferenciar regras e princípios é analisar as normas individualmente consideradas - antes, portanto, de analisar suas conexões e conflitos com outras normas.

Nesse sentido, os princípios apresentam indeterminação e um comportamento expansivo sobre o mundo dos fatos que não estão presentes nas regras. Eles podem ser identificados como mandamentos de maximização; têm, portanto, comandos prima facie progressivos, regulando todas as ações humanas e estados de coisas possíveis, enquanto as regras têm comandos prima facie estáticos, previamente limitados. 
Essa diferença comportamental é explicada por uma diferença estrutural: só os princípios têm a característica da indeterminação das ações humanas ou estados de coisas previstos em seu antecedente, que, por sua vez, é composto necessariamente por uma extensão ilimitada de condições disjuntivas.

Esses fatores marcam a diferença qualitativa entre as duas espécies normativas e explicam a maior apetência conflitual dos princípios. Todo o resto, a partir do conflito, parece não apontar para nenhuma distinção entre regras e princípios, mas apenas para o comportamento dessas normas em face de sua ocorrência.

\section{REFERÊNCIAS}

AARNIO, Aulis. Las reglas en serio. In: AARNIO, Aulis; GARZÓn VALDÉS, Ernesto; UUSITALO, Jyrki (comp.). La normatividad del derecho. Barcelona: Gedisa, 1997.

ALEXY, Robert. On the structure of legal principles. Ratio Juris, Medellín, v. 13, p. 294-304, 2000.

ALEXY, Robert. Constitutional rights, balancing, and rationality. Ratio Juris, Medellín, v. 16, p. 131-140, jun. 2003a.

ALEXY, Robert. On balancing and subsumption. A structural comparision. Ratio Juris, Medellín, v. 16, p. 433-449, 2003b.

ALEXY, Robert. Two or three? In: BOROWSKI, Martin (ed.). On the nature of legal principles. Stuttgart: Franz Steiner Verlag, 2010, p. 9-18.

ALEXY, Robert. Teoria dos direitos fundamentais. Trad. Virgílio Afonso da Silva. 2. ed. São Paulo: Malheiros, 2011a.

ALEXY, Robert. Deber ideal. In: CLÉRICO, Laura; SIECKMANN, Jan-Reinard; LALANA, Angel Daniel Oliver. Derechos fundamentales, principios y argumentación: estudios sobre la teoría jurídica de Robert Alexy. Granada: Comares, 2011b, p. 15-36.

ALEXY, Robert. Direitos constitucionais e fiscalização da constitucionalidade. Trad. Ana Margarida Gaudêncio e Luís Meneses doVale. Boletim da Faculdade de Direito de Coimbra, Coimbra, v. 88, p. 511-526, 2012. 
ALEXY, Robert. Formal principles: some replies to critics. International Journal of Constitutional Law, New York, v. 12, n. 3, p. 511-524, 2014.

ALEXY, Robert. "Dever” ideal e otimização. In: TOLEDO, Claudia (coord.). O pensamento de Robert Alexy como sistema. Rio de Janeiro: Forense, 2017.

ALONSO, Juan. The logical structure of principles in Alexy's Theory. A critical analysis. Revus - Journal for Constitutional Theory and Philosophy of Law, v. 28, p. 53-61, 2016.

ÁVILA, Humberto. Teoria dos princípios. 15. ed. São Paulo: Malheiros, 2014.

BÄCKER, Carsten. Regras, princípios e derrotabilidade. Trad. Tiago Lopes Mosci. Revista Brasileira de Estudos Políticos, Belo Horizonte, v. 102, p. 55-82, jan./jun. 2011.

BARROSO, Luís Roberto. Curso de Direito Constitucional contemporâneo: os conceitos fundamentais e a construção do novo modelo. 6. ed. São Paulo: Saraiva, 2017.

BRINDEIRO, Geraldo. Comentários ao art. 86 da Constituição Federal. In: BONAVIDES, Paulo; MIRANDA, Jorge; AGRA, Walber de Moura. Comentários à Constituição Federal de 1988. Rio de Janeiro: Forense, 2009.

BROZEK, Bartosz. Defeasibility of legal reasoning. Krakow: Zakamycze, 2004.

BROZEK, Bartosz. Rationality and discourse: towards a normative model of applying law. Warszawa: Oficyna, 2007.

BROZEK, Bartosz. Legal rules and principles: a theory revisited. i-lex, v. 17, p. 205-226, 2012.

CANOTILHO, José Gomes. Direito constitucional e teoria da Constituição. Coimbra: Almedina, 2003.

DUARTE, David. A norma de legalidade procedimental administrativa - a teoria da norma e a criação de normas de decisão na discricionariedade instrutória. Coimbra: Almedina, 2006.

DUARTE, David. Normative conditions of balancing: drawing up the boundaries of normative conflicts that lead to balances. Legal reasoning: the methods of balancing. Ed. Jan Sieckmann. Stuttgart: Franz Steiner Verlag, 2010, p. 51-61.

DUARTE, David. 15 minutos para 15 páginas: duas dúvidas para um problema essencial. Boletim da Faculdade de Direito/Universidade de Coimbra, Coimbra, v. 88, p. 527-536, 2012a. 
DUARTE, David. An experimental essay on the antecedent and its formulation. i-lex, v. 16, p. 37 $60,2012 b$.

DUARTE, David. Analogy and balancing: the partial reducibility thesis and its problems. Revus, v. 25, p. 141-154, 2015. Disponível em: http://revus.revues.org/3244. Acesso em: 5 maio 2019.

DWORKIN, Ronald. The model of rules. Faculty scholarship series. Paper 3609, 1967. Disponível em: http://digitalcommons.law.yale.edu/fss_papers/3609. Acesso em: 5 maio 2019.

DWORKIN, Ronald. Levando os direitos a sério. Trad. Nelson Boeira. São Paulo: Martins Fontes, 2002.

HART, Herbert Lionel Adolphus. The ascription of responsibility and rights. Proceedings of the Aristotelian Society. Londres, XLIX, p. 171-194, 1948.

HART, Herbert Lionel Adolphus. The concept of law. 2. ed. Oxford: Oxford University Press, 1994.

LOPES, Pedro Moniz. Derrotabilidade normativa e normas administrativas. Tese (Doutorado em Direito Ciências Jurídico-Políticas) - Universidade de Lisboa, Lisboa, v. 1, 2016.

LOPES, Pedro Moniz. Implicazioni derivanti dalla genericità sulla (in)coerenza e (in)completezza dei sistemi giuridici. Diritto \& Questioni Pubbliche, Palermo, I, XVII, p. 275-327, 2017.

MENDES, Gilmar Ferreira; BRANCO, Paulo Gustavo Gonet. Curso de Direito Constitucional. 11. ed. São Paulo: Saraiva, 2016.

NEVES, Marcelo. Entre Hidra e Hércules: princípios e regras constitucionais como diferença paradoxal do sistema jurídico. São Paulo: Martins Fontes, 2013.

PECZENIK, Aleksander. On law and reason. [S.l.]: Springer, 2008.

PINO, Giorgio. Diritti e interpretazione - Il ragionamento giuridico nello Stato constituzionale. Bolonha: Il Mulino, 2010.

PINO, Giorgio. Teoria analítica del diritto I - La norma giuridica. Pisa: Edizioni ETS, 2016.

POSCHER, Ralf. Aciertos, errores y falso autoconcepto de la teoría de los principios. In: SIECKMANN, Jan-Reinard. La teoría principialista de los derechos fundamentales: estudios sobre la teoría de los derechos fundamentales de Robert Alexy. [S.1.]: [s.n.], 2011, p. 71-92. 
POSCHER, Ralf. The principles theory: how many theories and what is their merit? In: KLATT, Matthias. Institutionalized reason. The jurisprudence of Robert Alexy. Oxford: Oxford Press, 2012.

POSCHER, Ralf. Theory of a phantom: the principles theory's futile quest for its object. In: OLIVEIRA, Júlio Aguiar de; PAULSON, Stanley L.; TRIVISONNO, Alexandre T. G. Alexy’s theory of law. Stuttgart: Franz Steiner Verlag, 2015, p. 129-148.

RAMIÃO, Ruben. Some fundamental problems concerning Alexy's notion of legal principles. In: DUARTE, David; SAMPAIO, Jorge Silva (eds.). Proportionality in law. [s.l.]: Springer, 2018, p. 157-170.

SACRAMENTO, Bruno. A ponderação genérica como instrumento de interferência judicial nas políticas públicas no Brasil: um estudo a partir do fornecimento de medicamentos não aprovados pela Anvisa. Los desafíos jurídicos a la gobernança global: una perspectiva para los próximos siglos. Brasília: Advocacia-Geral da União, 2017, p. 361-386.

SCHAUER, Frederick. Playing by the rules: a philosophical examination of rule-based decision-making in law and in life. New York: Oxford University Press, 1991.

SIECKMANN, Jan-R. Balancing, optimisation, and Alexy's “weight formula”. Legal reasoning: the methods of balancing. Stuttgart: Franz Steiner Verlag, 2010, p. 101-118.

SILVA, Luis Virgílio Afonso da. Princípios e regras: mitos e equívocos acerca de uma distinção. Revista Latino-Americana de Estudos Constitucionais. Belo Horizonte, v. I, p. 607-630, jan./jun. 2003.

SILVA, Luis Virgílio Afonso da. Direitos fundamentais: conteúdo essencial, restrições e eficácia. 2. ed. São Paulo: Malheiros, 2010.

SILVA, Luis Virgílio Afonso da. O Supremo Tribunal Federal precisa de Iolau: resposta às objeções de Marcelo Neves ao sopesamento e à otimização. Revista de Direito da Universidade de Brasilia, v. 2, p. 96-118, jan./abr. 2016.

ZORRILLA, David Martínez. Conflictos constitucionales, ponderación e indeterminación normativa. Madrid: Marcial Pons, 2007.

ZORRILLA, David Martínez. The structure of conflicts of fundamental legal rights. D. Law and Philos, v. 30, n. 6, p. 729-749, 2011.

ZORRILLA, David Martínez. Some thoughts about the limits of Alexy's conception of principles and balancing. In: DUARTE, David; SAMPAIO, Jorge Silva (eds.). Proportionality in law. [S.l.]: Springer, 2018, p. 171-192. 


\section{COMO CITAR ESTE ARTIGO:}

SACRAMENTO, Bruno. A ponderação de regras e alguns problemas da teoria dos princípios de Robert Alexy. Revista Direito GV, v. 15, n. 2, 2019, e1917. doi: http://dx.doi.org/10.1590/23176172201917.

\section{Bruno Sacramento}

Mestrando em Direitos Fundamentais pela Faculdade de Direito da Universidade de LisBoA, Lisboa, Portugal. PESquisador dO PROGRAMA ERASMUS+ PELA UNIVERSITÀ DEgLI StUdi dI ROMA “TOR Vergata”, Roma, Itália. Especialista em DiReito do Estado (Pós-graduação lato SENSU) PELA Universidade FEDERAL dO RIO GRANDE dO SUL (UFRGS) e Bacharel em DiReito PELA Universidade Federal de Pelotas (UfPel). Advogado da União lotado na Procuradoria-Seccional da União em Pelotas, Rio Grande do Sul. Atualmente, exerce suas funções na CoOrdenação Regional de Recuperação de Ativos (Corat - PRU4).

bruno.sacramentolayahoo.com 


\section{ERRATA}

http://dx.doi.org/10.1590/2317-6172201925

No artigo "A PONDERAÇÃo DE REgRAS E ALGUNS PROBlemas DA TEORIA DOS PRINCÍPIOS De Robert Alexy”, DOI: HTTP:/ / DX.DOI.ORg/10.1590/2317-6172201917, PUblicAdo no periódico ReVISta Direito GV, i 5(2), ei 9 i 7 , em razão de erros Que ocorreram durante o processo de edição do respectivo artigo pela Revista Direito GV, e que, PORTANTO, DEIXARAM-NO EM DESCONFORMIDADE COM A VERSÃO QUE HAVIA SIDO APROVADA PARA PUBLICAÇÃO, INFORMAMOS QUE:

NA PÁGINA I:

ONDE SE LIA:

"Bruno Sacramento Santos Silva"

\section{LEIA-SE:}

"Bruno Sacramento"

NA PÁGINA I I :

\section{ONDE SE LIA:}

"A possibilidade de excepcionalmente não ocorrer a ativação das consequências jurídicas de uma norma, mesmo que preenchidas as condições de seu antecedente, demonstra que essas condições são apenas necessárias, mas não suficientes. Para que ocorra o efeito jurídico previsto, deve-se verificar as outras normas relevantes para o caso concreto em que podem, em razão de eventuais efeitos colidentes, derrotar a norma de partida (LOPES, 2016, p. 124-125). O fenômeno da derrotabilidade atesta, assim, o caráter prima facie das normas.”

\section{LEIA-SE:}

“A possibilidade de excepcionalmente não ocorrer a ativação das consequências jurídicas de uma norma, mesmo que preenchidas as condições de seu antecedente, demonstra que essas condições são apenas necessárias, mas não suficientes. Para que ocorra o efeito jurídico previsto, deve-se verificar as outras normas relevantes para o caso concreto que podem, em razão de eventuais efeitos colidentes, derrotar a norma de partida (LOPES, 2016, p. 124-125). O fenômeno da derrotabilidade atesta, assim, o caráter prima facie das normas." 
NA PÁGINA I 2:

\section{ONDE SE LIA:}

“(13) Assim, em face da situação concreta (5), são aplicáveis as normas (6) e (7), gerando um conflito (12) só solucionável por ponderação, do que resulta: definitividade (regulação prima facie). ${ }^{26}$ "

\section{LEIA-SE:}

“(13) Assim, em face da situação concreta (5), são aplicáveis as normas (6) e (7), gerando um conflito (12) só solucionável por ponderação, do que resulta: $\vdash$ definitividade (regulação prima facie). ${ }^{26}$ "

NA PÁGINA 24:

\section{ONDE SE LIA:}

“(28) $\mathrm{R}=$ (determinação), (expansividade).”

\section{LEIA-SE:}

“(28) $\mathrm{R}=$ (determinação), ( $\vdash$ expansividade $).$

NA PÁGINA 3 I, NO MINICURRÍcUlo DO AUTOR:

\section{ONDE SE LIA:}

\section{Bruno Sacramento Santos Silva}

Mestrando em Direitos Fundamentais pela Faculdade de Direito da Universidade de Lisboa, Lisboa, Portugal. Pesquisador do Programa ERASMUS+ pela Università degli Studi di Roma “Tor Vergata”, Roma, Itália. Especialista em Direito do Estado (pós-graduação lato sensu) pela Universidade Federal do Rio Grande do Sul (UFRGS) e Bacharel em Direito pela Universidade Federal de Pelotas (UFPel). Advogado da União lotado na Procuradoria-Seccional da União em Pelotas, Rio Grande do Sul. Atualmente, exerce suas funções na Coordenação Regional de Recuperação de Ativos (Corat - PRU4).

bruno.sacramento@yahoo.com

\section{LEIA-SE:}

\section{Bruno Sacramento}

Mestrando em Direitos Fundamentais pela Faculdade de Direito da Universidade de Lisboa, Lisboa, Portugal. Pesquisador do Programa ERASMUS+ pela Università degli Studi di 
Roma "Tor Vergata", Roma, Itália. Especialista em Direito do Estado (pós-graduação lato sensu) pela Universidade Federal do Rio Grande do Sul (UFRGS) e Bacharel em Direito pela Universidade Federal de Pelotas (UFPel). Advogado da União lotado na Procuradoria-Seccional da União em Pelotas, Rio Grande do Sul. Atualmente, exerce suas funções na Coordenação Regional de Recuperação de Ativos (Corat - PRU4).

bruno.sacramento@yahoo.com

Na página 3 I, NO boXe "Como Citar este artigo":

\section{ONDE SE LIA:}

SILVA, Bruno Sacramento Santos. A ponderação de regras e alguns problemas da teoria dos princípios de Robert Alexy. Revista Direito GV, v. 15, n. 2, 2019, e1917. doi: http://dx.doi.org/ 10.1590/2317-6172201917.

\section{LEIA-SE:}

SACRAMENTO, Bruno. A ponderação de regras e alguns problemas da teoria dos princípios de Robert Alexy. Revista Direito GV, v. 15, n. 2, 2019, e1917. doi: http://dx.doi.org/ 10.1590/2317-6172201917. 